\title{
Envisaging the Sustainability of an Aquifer by Developing Groundwater Flow Model for a Part of Choutuppal Mandal, Nalgonda District, Telangana, India
}

\author{
Pawan Kumar Neupane ${ }^{1,2^{*}}$, Nepal Chandra Mondal ${ }^{1}$ and Ajay Manglik ${ }^{1}$ \\ ${ }^{I}$ CSIR-National Geophysical Research Institute, Hyderabad, India \\ ${ }^{2}$ Nepal Academy of Science and Technology (NAST), Lalitpur, Nepal \\ *Corresponding Author \\ pawan.usk@gmail.com
}

\begin{abstract}
Recurring droughts and increased exploitation of groundwater to meet the growing water needs have resulted in the decline of regional groundwater level and drying weathered zone in a part of the Choutuppal Mandal, Nalgonda district, Telangana, India. In this study, a preliminary steady state groundwater flow modelling has been carried out by using Visual MODFLOW Classic Interface (Build 4.6.0.168), well inventory data from the existing 20 observation wells and a base map for the subsurface structure in order to evolve the future pumping schemes. The area spreading about $0.43 \mathrm{~km}^{2}$ is conceptualized as a two-layered model consisting of a weathered layer overlying a fractured aquifer. The model has been digitized into grids of $5 \mathrm{~m} \times 5 \mathrm{~m}$ in each layer. The integrated finite difference method has been utilized to discretize the groundwater flow equation and simulate groundwater flow with the help of calculated parameters along with the boundary conditions and acting stresses. Results show that the computed groundwater levels are in good agreement with the observed heads, and groundwater is flowing from the South to the North direction. The estimated velocities vary from 0.01 to $1.95 \mathrm{~m} / \mathrm{d}$. The optimum pumping schemes have also been simulated up to the year 2022. It has been observed that the maximum pumping rate should not go beyond $24 \mathrm{~m}^{3} /$ day. Since the drinking water demand (10-15 $\mathrm{m}^{3} /$ day) in the study site is below this limit, it can be inferred that the aquifer will sustain and provide enough drinking water.
\end{abstract}

\section{Keywords}

Groundwater, weathered and fractured aquifers, numerical simulation, MODFLOW, Choutuppal.

\section{Introduction}

Groundwater is indispensable for sustaining human life, economic growth, and a healthy ecosystem (Gleeson et al., 2012). Since groundwater is an essential source of water in semi-arid and drought-prone regions, it is imperative to understand groundwater quantity and quality along with flow conditioning these regions for sustainable aquifer management (Guihéneuf et al., 2014). Groundwater models can be used to develop such understandings and help in an informed decision-making process. These models represent the essential features of the actual groundwater systems employing a mathematical counterpart (Alley, 1999) and generate precise information for water resources management, groundwater protection, and remediation (Baalousha, 2008). The necessities of building the models comprehensively increase in the regions, which are complemented by undue exploitation of groundwater in order to fulfill the daily water demand. These models could be steady-state or transient, confined or unconfined or combined, one-dimensional, two-dimensional, quasi three-dimensional, or three-dimensional, which can be solved by using finite difference methods or finite element methods or combination of both (Todd \& Mays, 2005).

Groundwater Modeling System (GMS), Finite Element Subsurface Flow System 
(FEFLOW), Modular Finite-difference Flow Model (MODFLOW), etc. are some of the advantageous software that has been developed to build groundwater models applicable for groundwater resource management. Such software can be applied to assess the waterlogged area (Singh 2013), simulate drawdown (Sklorz et al., 2017), and determine the interactions between the surface water and groundwater (Lasya \& Inayathulla 2015). simulations (Waterloo Hydrogeologic 2015). Fouépé Takounjou et al., (2009); Jovanovic (2009); Mondal and Singh (2009); Shi (2010); Mondal and Singh (2012); Saghravani et al., (2012); Steiakakis et al., (2016); Baharuddin et al., (2016); Kumar et al., (2017) and Sen et al., (2018) applied Visual MODFLOW for various research purposes. Based on the review study of research papers, Hariharan and Uma Shankar (2017) and Mondal (2019) found that Visual MODFLOW can be applied in a variety of groundwater flow

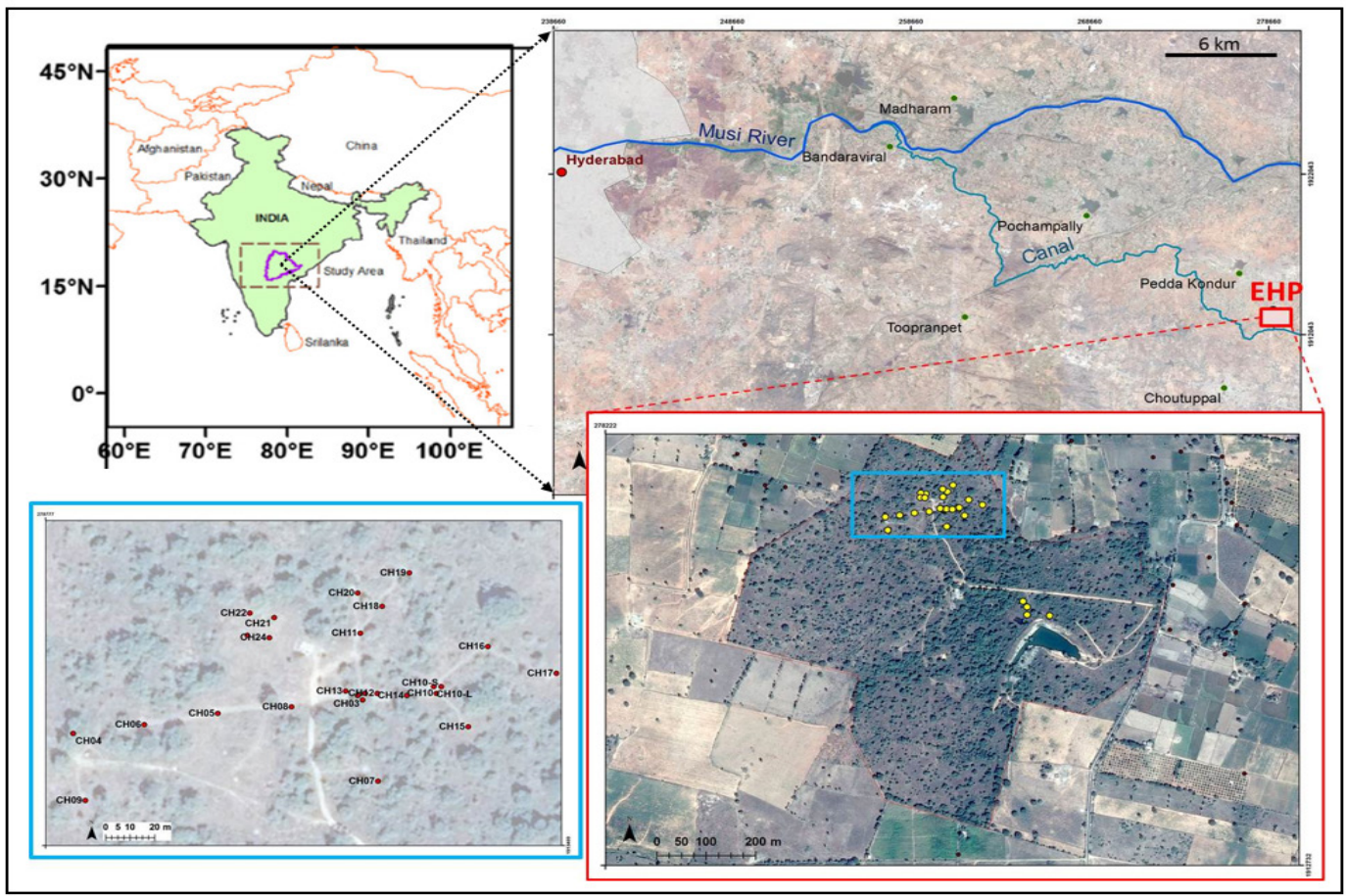

Fig. 1. Showing the EHP site with the observation wells, Choutuppal Mandal, Nalgonda District, Telangana, India (Image Source: Google Earth, retrieved on 20 January 2019)

MODFLOW, developed initially by McDonald \& Harbaugh (1988), is now added with many capabilities to make it user friendly. Most of the hydraulically defined groundwater flows simulated by MODFLOW were independently verified as rationally isotope mixing model (Carrol et al., 2008). Visual MODFLOW, an integrated package combining MODFLOW, MODPATH, and Zone Budget, is the most complete and comprehensible modeling setting that can be applied conveniently in three-dimensional groundwater flow and contaminant transport simulation settings. Considering the full range of applicability and reliability of Visual MODFLOW, this study is aimed to develop a preliminary steadystate groundwater flow model for an experimental site using Visual MODFLOW Classic Interface (Build: 4.6.0.168). This model would be helpful to evolve the future pumping schemes in the study site located at Choutuppal Village, Nalgonda district, Telangana, India (Fig. 1).

\section{Study area}

The Experimental Hydrogeological Park (EHP) (Latitudes: 17²1 $23.5^{\prime \prime}-17^{\circ} 17^{\prime} 52.5^{\prime \prime} \mathrm{N}$; 
Longitudes: $78^{\circ} 54^{\prime} 59.2^{\prime \prime}-78^{\circ} 55^{\prime} 27.6^{\prime \prime} \mathrm{E}$ ) is situated in the Nalgonda district close to Choutuppal village in Telangana state, $60 \mathrm{~km}$ south-east of Hyderabad city (Fig. 1). Constituted of weathered and fractured Archean granite, the EHP site covers an area of $0.43 \mathrm{~km}^{2}$ with an altitude range of 363 to $375 \mathrm{~m}$ (Fig.2). The EHP site has more than 28 boreholes (available 20 boreholes data were used for this study) that are being used for studying aquifer properties.

\section{Geological structure}

The typical geological profiles of two boreholes (shown in Fig. 3) are obtained at the EHP by drill cuttings analysis. The lithological description is given by Guiheneuf et al., (2014), which are from top to bottom up to the explored depth of around $80 \mathrm{~m}$, below ground level (bgl). It has been observed that the top red sandy soil ranges from the first decimeters to the first meter. The sandy regolith is varied from about $1-3 \mathrm{~m}$ deep, and the saprolite (mainly laminate structure) is from about 3 to $13-24 \mathrm{~m}$ deep. It is derived from the in-situ et al., 2017). The upper part of the granite is highly weathered and fractured, but the fracture frequency decreases rapidly with the depth.

\section{Climatic condition}

Nalgonda district has a semi-arid climate with an average annual temperature of $28^{\circ} \mathrm{C}$ and a maximum of $45^{\circ} \mathrm{C}$ in the summer season. The mean annual rainfall is around $751 \mathrm{~mm}$, which ranges from $2 \mathrm{~mm}$ in February to $171 \mathrm{~mm}$ in July. The dug well depth ranges from 30 to $300 \mathrm{~m}$ below the ground surface ( $\mathrm{m} \mathrm{bgs}$ ) in the district (CGWB, 2013). Water levels at the district are highly variable depending on the monsoon and usually range between 2 and $26 \mathrm{~m}$ ( $\mathrm{m} \mathrm{bgs}$ ). Water level measurement at the EHP site during the last four years has shown that only monsoon precipitation has recharged the aquifer.

\section{Methods}

The Visual MODFLOW Classic Interface was used, which can simulate the groundwater flow model under the steady and transient states

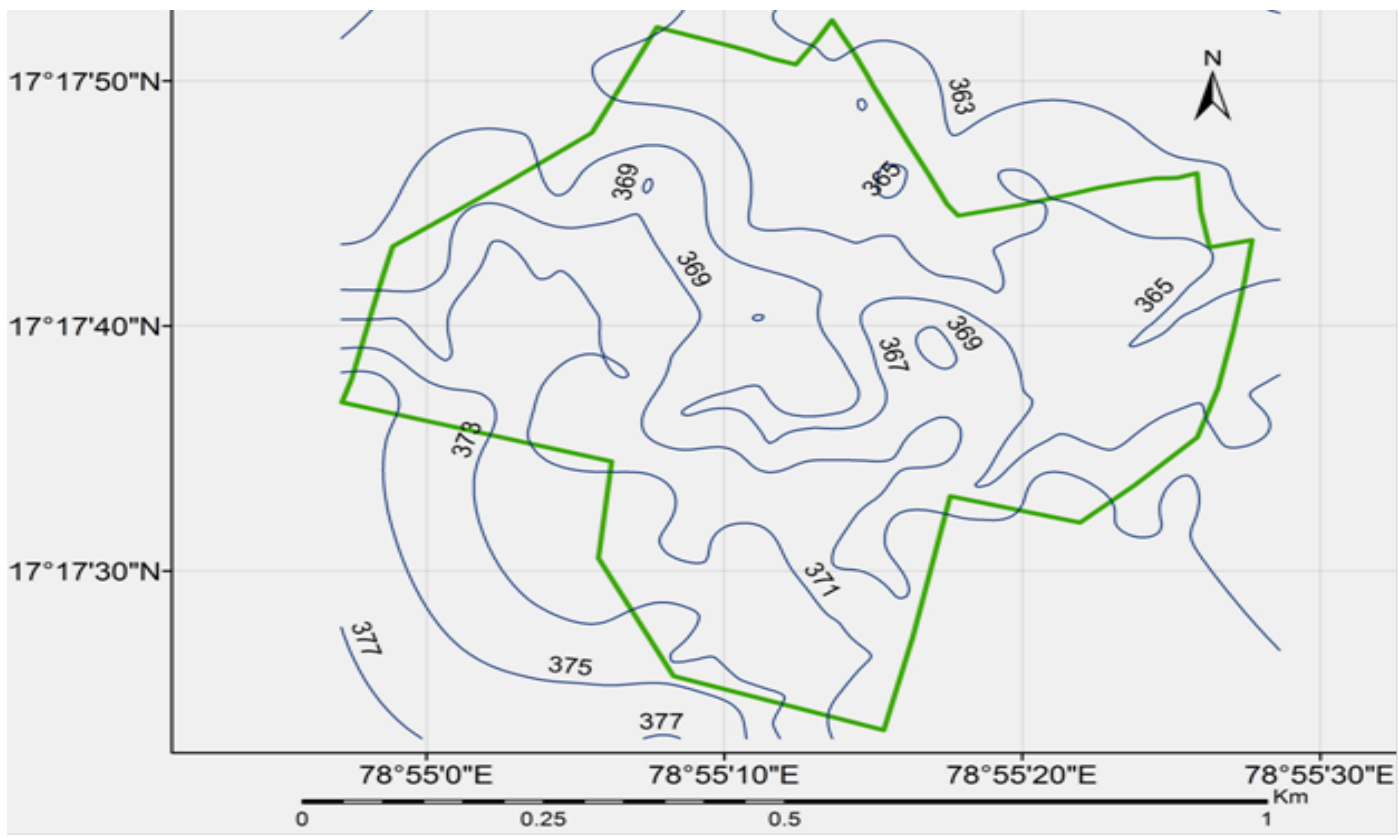

Fig. 2. Topography contour map (in m, amsl) of the EHP in ChoutuppalMandal, Nalgonda District, Telangana, India

weathering of granitic rocks. In the deeper part, poorly fractured crystalline rock overlies upon the fresh basement (Boisson et al., 2015; Guihéneuf either 1-D, 2-D, or 3-D for both anisotropic and heterogeneous systems by adopting the 


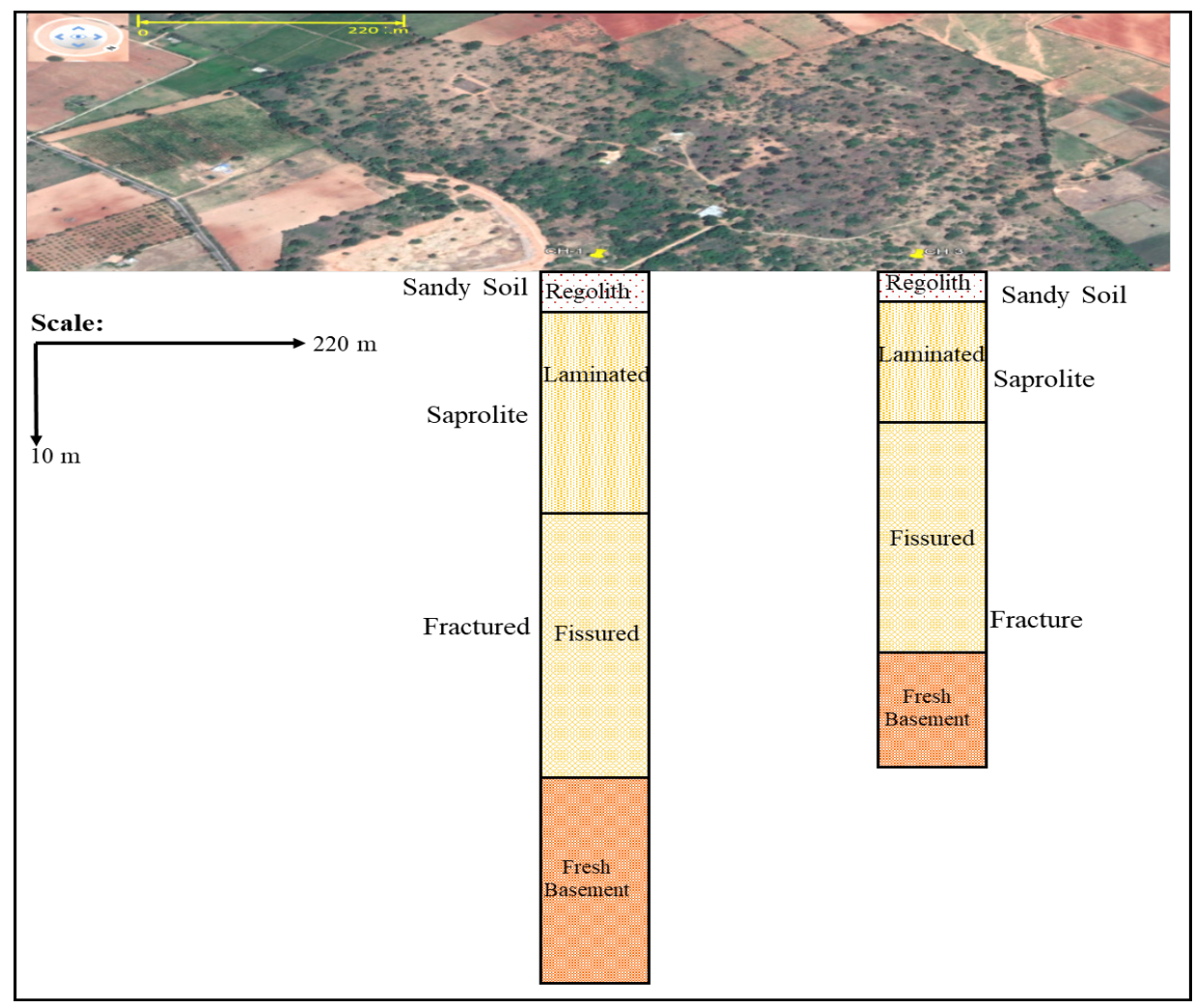

Fig.3. Showing the typical lithology (at CH1 and CH2) of the EHP Site ( Image Source: Google Earth, retrieved on 20 January 2019)

finite-difference method. The governing 3-D groundwater flow equation used by MODFLOW (McDonald \& Harbaugh 1988) is as below.

$$
\frac{\partial\left(K_{x} \frac{\partial h}{\partial x}\right)}{\partial x}+\frac{\partial\left(K_{y} \frac{\partial h}{\partial y}\right)}{\partial y}+\frac{\partial\left(K_{z} \frac{\partial h}{\partial z}\right)}{\partial z}+q_{s}=S_{S} \frac{\partial \mathrm{h}}{\partial \mathrm{t}}
$$

Where, $\mathrm{K}_{\mathrm{x}}, \mathrm{K}_{\mathrm{y}}$ and $\mathrm{K}_{\mathrm{z}}$ are the values of hydraulic conductivity along the $\mathrm{x}, \mathrm{y}$, and $\mathrm{z}$ coordinate axes oriented parallel to the principal axes of hydraulic conductivity $[\mathrm{L} / \mathrm{T}], \mathrm{h}$ is the hydraulic head $[\mathrm{L}], \mathrm{q}_{\mathrm{s}}$ is the volumetric flux of groundwater sources and sinks per unit volume $[1 / \mathrm{T}]$ with positive values indicating flow into the groundwater system, $\mathrm{S}_{\mathrm{s}}$ is specific storage $[1 / \mathrm{L}]$, and $\mathrm{t}[\mathrm{T}]$ is time.

The modeling process involves necessary steps that include objective identification, data collection, and review, model conceptualization, model design, model run, model calibration along with improvements in the conceptual model, verification of the model, analysis of sensitivity and uncertainty, and finally reporting the outcome. The methodology generally adopted to set up a groundwater model is described in the flow chart mentioned in Fig.4. For this study, the same steps were followed to develop a steady-state groundwater flow model.

\section{Data collection}

Elevation data of the EHP site were collected from Google Earth Map using a TCX converter with an accuracy of $\pm 5.0 \mathrm{~m}$. To maintain the accuracy, 20 elevation data collected at the observation wells were compared with the field level Global Positioning System (GPS) data that showed on an average variation of $+2.0 \mathrm{~m}$. The altitude data deduced from the Google Earth Map have been corrected accordingly by reducing $2.0 \mathrm{~m}$ and used for this study.

Published literature was reviewed to collect hydro-geological and lithological information of the EHP site (Boisson et al., 2015; Guihéneuf et 


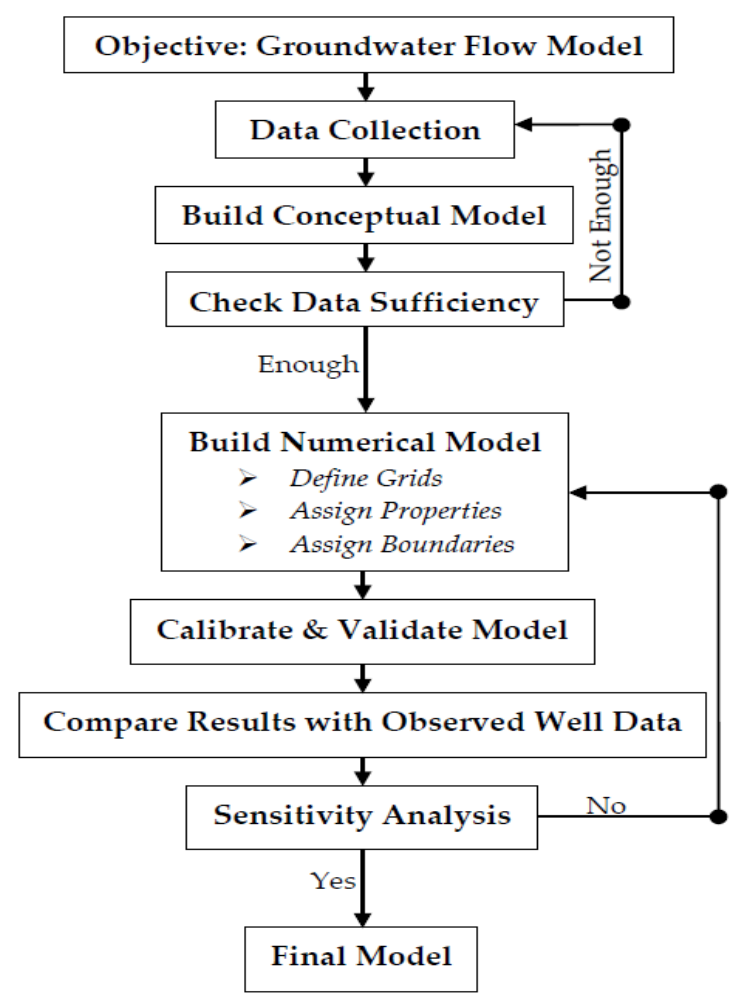

Fig.4. Methodological flow chart to develop a groundwater flow model

al., 2014; and Guihéneuf et al., 2017).

\section{Conceptualization and grid design}

The conceptualization of the flow regime was conducted based on hydro-geological information collected from the literature review and existing physical conditions of the site.The model was divided into grids of $5 \mathrm{~m} \times 5 \mathrm{~m}$ (Fig.5) in each layer represented with 17,200 active cells. The area spreading about $0.43 \mathrm{~km}^{2}$ was conceptualized as a two-layered model consisting of a weathered layer overlying a fractured aquifer, as mentioned in Fig.6.

The top layer was considered as an unconfined aquifer, whereas the bottom layer was assumed to be confined aquifer. The top layer, weathered zone, lies in between $2-24 \mathrm{~m}$, bgs underlying by $15-80 \mathrm{~m}$ fractured/semi-weathered layer. The top of the first layer (namely shallow aquifer) varied from 333 to $362 \mathrm{~m}$ (amsl), while the bottom of the second aquifer ranged from 261.0 to $285.7 \mathrm{~m}$ (amsl). These two layers have different hydraulic characteristics, and especially the fractured zone/semi-weathered layer has a lower storage coefficient comparatively the weathered zone. This weathered aquifer was considered as equivalent to a porous one. For the saturated zone connectivity in fractured media/semi-weathered layer, although a general decrease of the hydraulic conductivity with depth is known, only minimal information is available on the vertical connectivity of the dominant horizontal fracture network. This connectivity has been investigated through packer tests at a localized scale (Boisson et al., 2015) and indicated the semi-weathered layer with a large fracture density having low storativity. Thus the semi-weathered/fractured layer was also assumed to be a porous layer for the groundwater flow modelling.

\section{Assignment of boundary conditions}

The study site slightly slopes towards the North. Streams or rivers are absent. So, the constant head boundary was taken for the steady-state simulation towards the North direction of the 


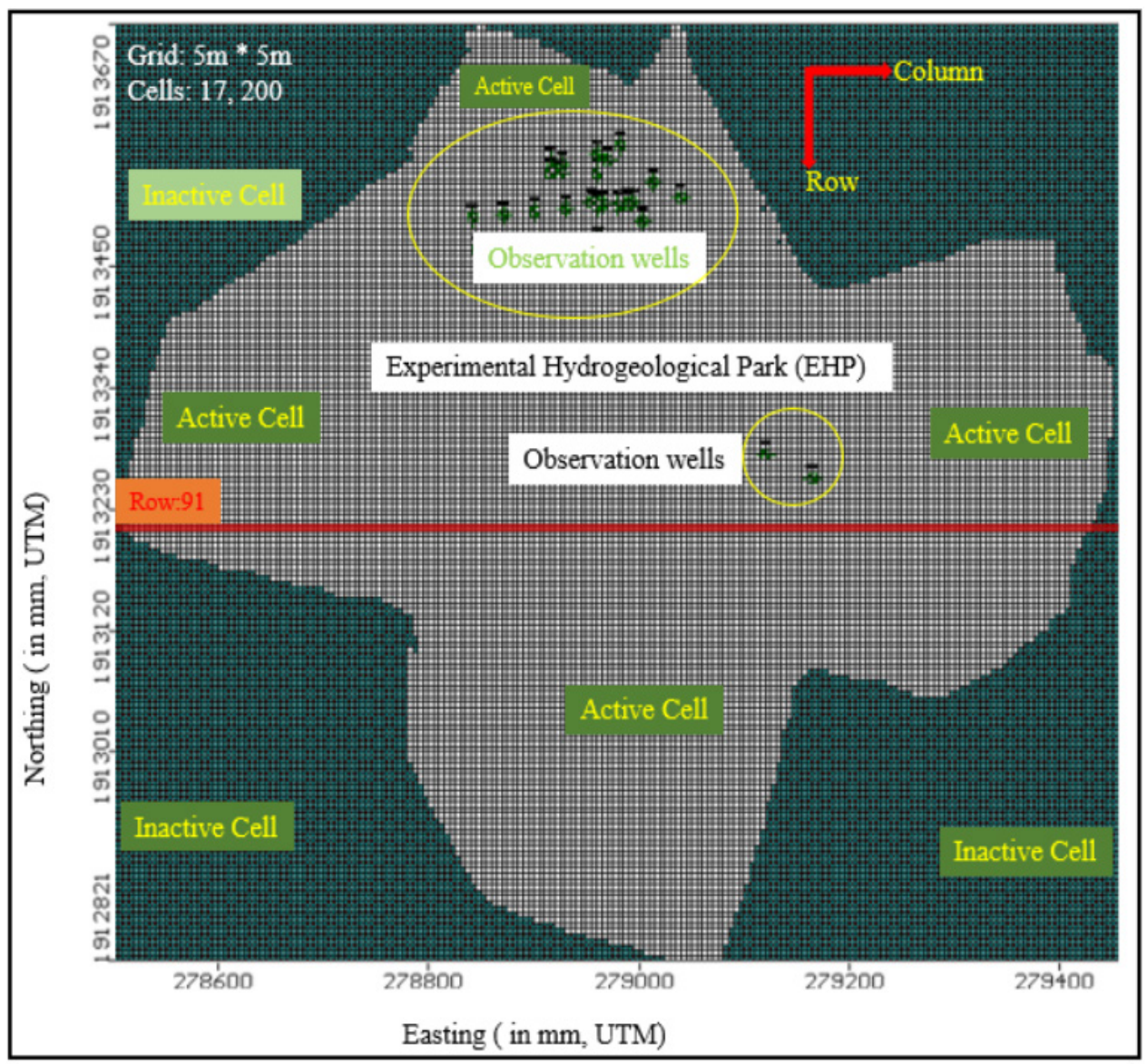

Fig.5. Grids of $5 \mathrm{~m} \times 5 \mathrm{~m}$ in the modeled area

micro-watershed. A constant head of $335 \mathrm{~m}$ (amsl) was taken in the model simulation. The no-flow boundaries were assigned in the other three sites of the watershed, where the water divides were observed and the watershed has only one outlet in the northern part.

\section{Assignment of aquifer properties}

Hydraulic conductivity and recharge values, along with the porosity, specific yield, specific retention, and specific storage, were assigned to each layer. The hydraulic conductivity of the first layer varies between 0.0864 and $8.64 \mathrm{~m} / \mathrm{d}$ (Guihéneuf et al., 2014). For this study, layer one was divided into three zones based on the variations of geological conditions, and hydraulic conductivity values were assigned as 5, 4, and $3 \mathrm{~m} / \mathrm{d}$, respectively, for Zones 1, 2, and 3 (Fig. 7). The hydraulic conductivity value of the second layer was calculated by interpolating the observed conductivity values at the observation wells using the Krigging method in the MODFLOW environment. The interpolated conductivity value for layer 2 ranges from 0.04 to $0.864 \mathrm{~m} / \mathrm{d}$. A maximum conductivity value of $0.864 \mathrm{~m} / \mathrm{d}$ lies in the North-Eastern part, and the minimum value of 0.04 lies in the Southern part.

The mean annual rainfall in the study area inthe year 2013 was about $1101 \mathrm{~mm}$. Recharge is assumed to be $2-15 \%$ (Lerner et al., 1990) of the annual rainfall in the semi-arid area, which was utilized for the natural groundwater reserve in the model. Therefore, the recharge values varied from 22.02 to $165.15 \mathrm{~mm} / \mathrm{yr}$. The recharge values assigned were 70,80 , and $90 \mathrm{~mm} / \mathrm{yr}$, respectively, for Zones 1, 2, and 3 (Fig. 8). Irrigation recharge was not considered due to the unavailability of data, which was not practiced in the modeled area. The assigned values of the other layer properties 


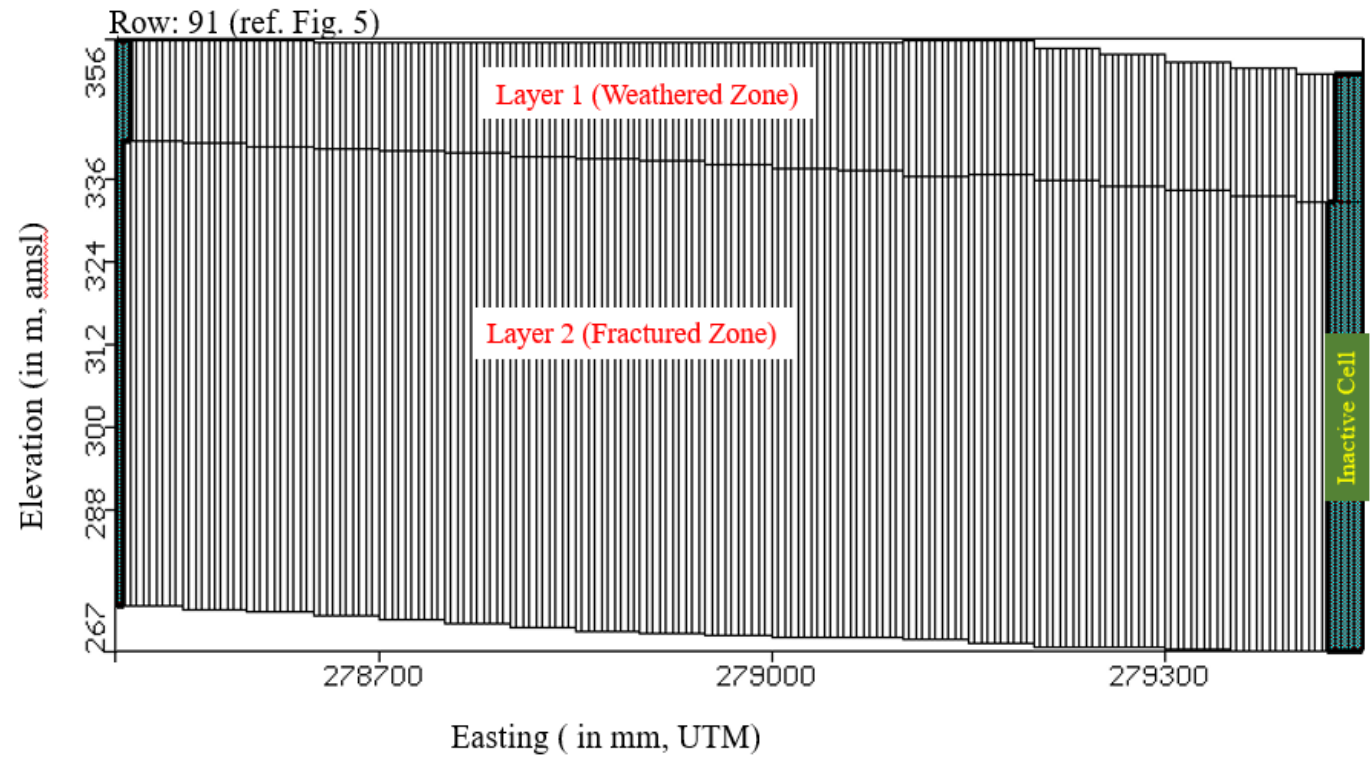

Fig.6. Cross-section view of the two-layered conceptual model of the EHP site at the Row: 91

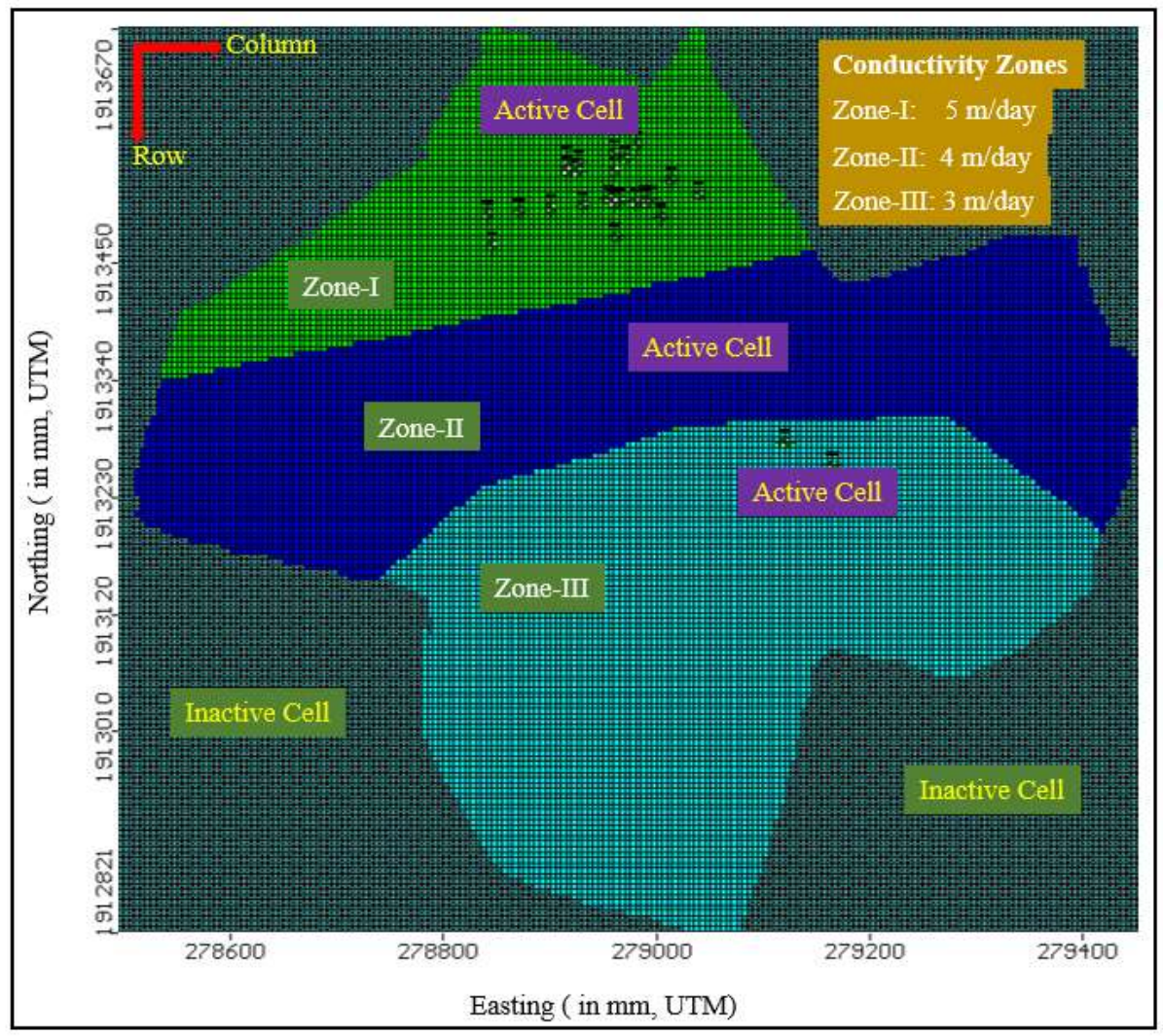

Fig.7.Showing the $\mathrm{K}$ - distribution in the first layer 


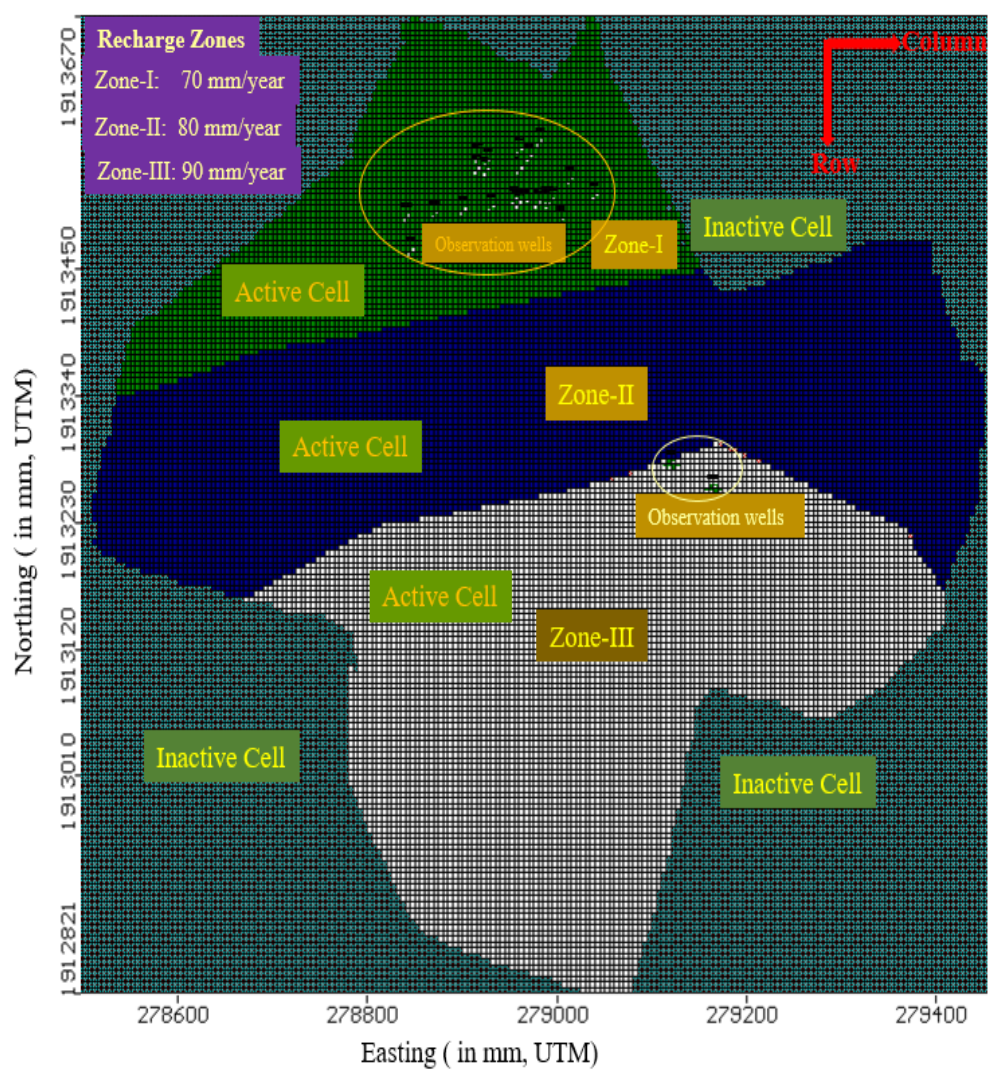

Fig. 8. Showing assigned recharge values (in $\mathrm{mm} / \mathrm{year}$ ) for the EHP site

were as given in Table 1.

Table 1. Other aquifer properties assigned to layers 1 and 2

\begin{tabular}{lll}
\hline Properties & Layer-1 & Layer-2 \\
\hline Porosity (\%) & 25 & 5 \\
Specific Yield (\%) & 12.5 & 2 \\
$\begin{array}{l}\text { Specific Storage } \\
(1 / \mathrm{m})\end{array}$ & $1.032 \times 10^{-4}$ & $9.91 \times 10^{-5}$ \\
\hline
\end{tabular}

\section{Steady-state model}

The purpose of the steady-state groundwater model is to demonstrate that the model can reproduce field measured heads and flows. The flow model was calibrated by adjusting numerous parameters such as recharge, conductivity, and porosity, etc. within an acceptable limit until the best fit was obtained between the observed and calibrated heads. The accuracy of the computed heads was judged by the root mean square error among the computed and observed head plots on the graph.

The groundwater steady-state flow model was developed for 365 days using available 20 observation wells data. The model was calibrated against the constant head boundary, recharge, and hydraulic conductivity through a sequence of sensitivity analysis runs. The values were adjusted during trial and error runs aiming at the smallest root mean square errors at the targets.Groundwater levels measured were used as initial water level conditions.

\section{Sensitivity Analysis}

Sensitivity analysis was performed in order to notice the effect of uncertainties on the calibrated model. It involved a series of simulations on the outcome model by changing the values of assigned aquifer parameters and boundary conditions. During the analysis, one parameter was changed with in a conceivable range by increasing and decreasing the value of the parameter multipliers. 


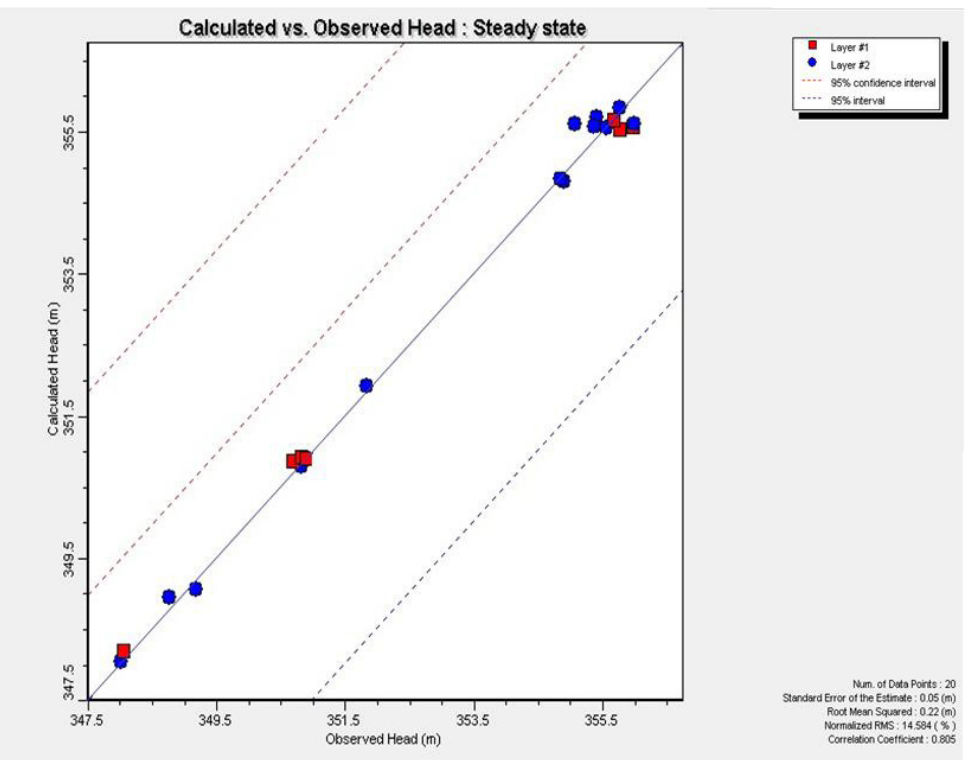

Fig.9. Calculated vs. observed heads in the steady-state calibration

\section{Mass Balance}

The results from steady-state or transient MODFLOW simulations can also be used to calculate sub-regional water budgets. The U.S. Geological Survey has developed a zone budget tool to calculate water budgets for user-defined zones in the model. This study applied the zone Budget tool to quantify the water balance and contributions of assigned parameters to the aquifer system.

\section{Results and Discussion}

The calibrated groundwater heads were in good agreement with the observed heads. The observed heads ranged from 348.42 to $356.18 \mathrm{~m}$, amsl, and the calibrated heads ranged from $348.47 \mathrm{~m}$ to $356.83 \mathrm{~m}$. The groundwater velocity vectors indicated the predominant flow towards the North with a velocity of $0.02 \mathrm{~m} / \mathrm{d}$ in layer 2. In Fig.9, the observed and calculated head values of well CH11 are closely simulated with an overestimation of $+0.05 \mathrm{~m}$, and the maximum over estimation of 0.77 $\mathrm{m}$ is at the well CH06 of the model. MODFLOW application may produce several reasonable as well as some unsatisfying simulations because of the complex hydrogeologic systems (Khadri $\&$ Pande 2016). One of the common ways to determine the accuracy of the results of calibration is calculating the root mean square error (RMS) value. The calibration result of the study has a low RMS value of $0.22 \mathrm{~m}$ (Fig. 9), demonstrating its satisfying responses to field measured heads. The results of the sensitivity analysis showed that the models are sensitive or reacting much to the parameters like hydraulic conductivity and recharge from rainfall in the different hydrogeological zones (Fig. 10). The micro-model is sensitive to the recharge in zone 3, resulting in a high RMS value than the other zones. The model is also comparatively more sensitive to hydraulic conductivity in Zone 1. The maximum RMS value obtained was 2.038 during the sensitivity analysis.

An outflow of $106.38 \mathrm{~m}^{3} /$ day was taken up by the Constant Head Boundary (CHB), and $1.81 \mathrm{~m}^{3} /$ day of groundwater was being used up by evapotranspiration. The inflow of the system was about $92.72 \mathrm{~m}^{3} /$ day. There was an overdraft taken only by the CHB because of there was no predominant abstraction well for the pumping.

The optimum pumping schemes simulated till the year 2022, assuming the population of 1200 based on the current growth rate of $1.36 \%$ at nearby villages, showed that the maximum pumping rate should not go beyond $24 \mathrm{~m}^{3} /$ day within this microwatershed taken one representative bore well (at the $\mathrm{CH} 4$, Fig.11). Since the drinking water demand (10-15 $\mathrm{m}^{3} /$ day) nearby the study site 

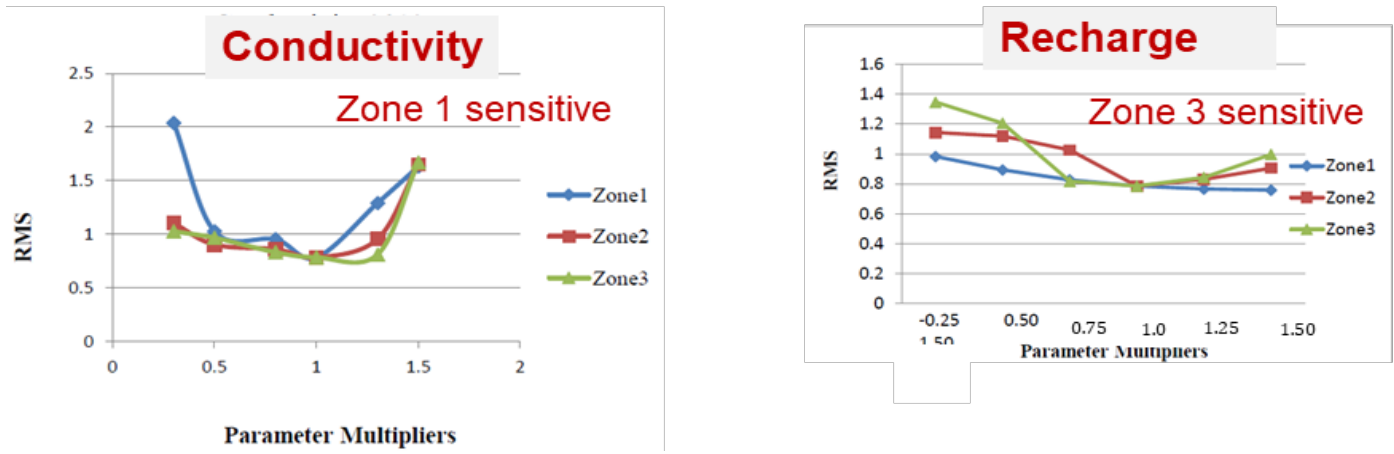

Fig. 10. Sensitive analysis of the flow model due to the hydraulic conductivity and recharge

is below this limit, it can be considered that the aquifer will sustain and provide enough drinking water to nearby the villages.
Hydrogeological Park (EHP) at Choutuppal Mandal, Nalgonda district, Telangana, India. The computed groundwater heads have shown to replicate the trend of observed groundwater

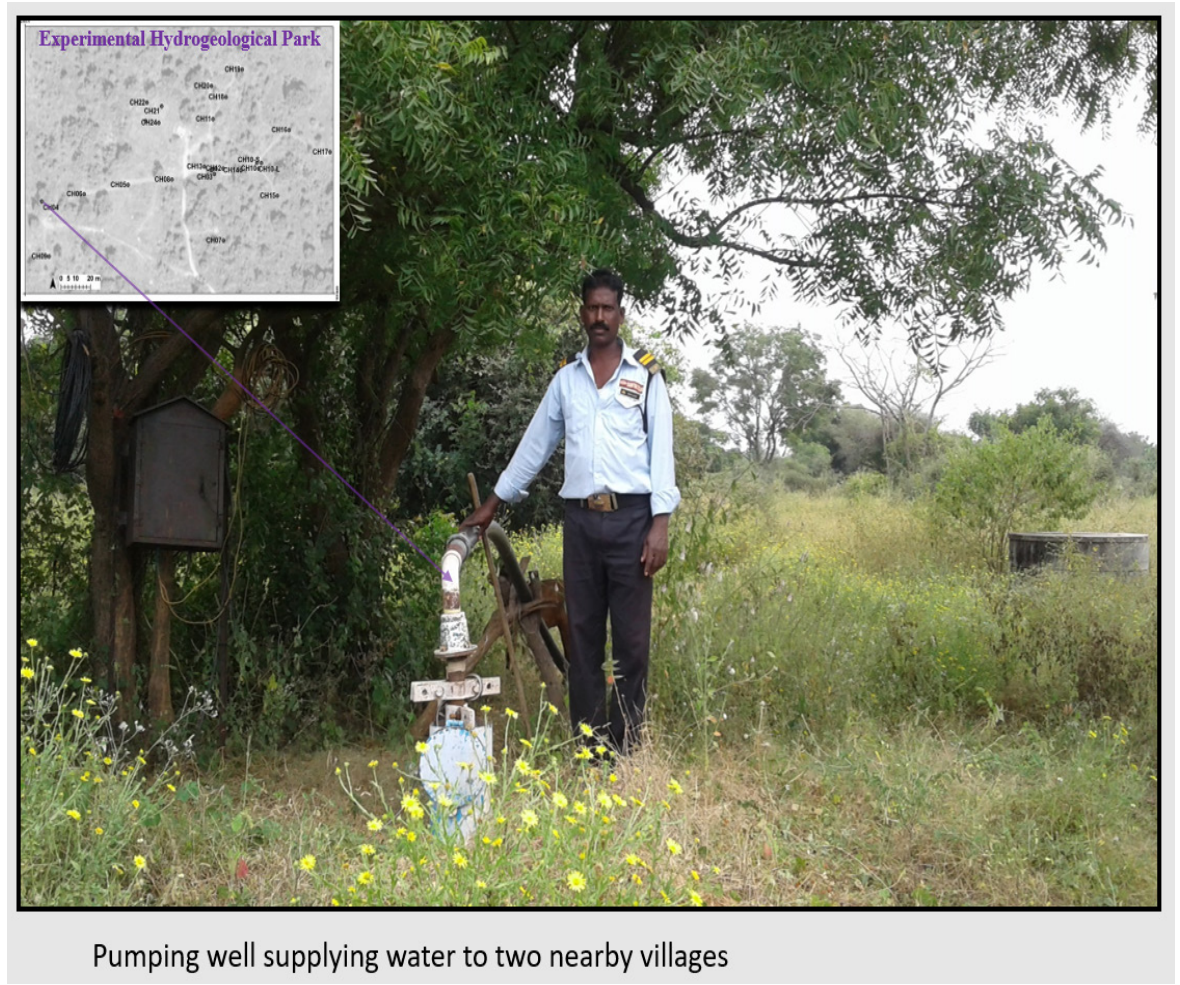

Fig.11. Showing a representative bore well (CH4) at the EHP site, Chouttupal, Nalgonda district to be used for the drinking water supply by nearby villagers

\section{Conclusion}

A groundwater model has been conceptualized and developed using the lithology information and aquifer parameters for the Experimental heads. Groundwater is flowing from the South to the North direction, with the velocity ranges of 0.01 to $1.95 \mathrm{~m} / \mathrm{d}$. The output from the calibrated model can be used to develop the transient state, 
particle tracking, and mass transportation models that will help in understanding the groundwater regime in the EHP. Further, the updated data can be used to refine the model and compare the findings with the model developed in this study to observe the accuracy of the assigned parameters. The current study has found that the maximum pumping rate should not go beyond $24 \mathrm{~m}^{3} /$ day for the drinking water supply to neighboring villages. The updated model may be applied to project the future scenarios of the aquifer system and estimate the sustainable pumping scheme at the EHP.

\section{Acknowledgments}

The work has been carried out under the Indian Science and Research Fellowship (ISRF) to the first author (Grant number: DO/CCSTDS/027/2018). This is gratefully acknowledged. Dr. V.M. Tiwari, Director, CSIR-NGRI, Hyderabad, India, is acknowledged for providing all necessary support for this work and according to approval for its publication (Ref. No. NGRI/Lib/2019/Pub-34). We are thankful to the scientists of CSIR-NGRI for their support in collecting published data and literature.

\section{References}

Alley, W.M., T.E. Reilly, and O.I. Franke. 1999. Sustainability of groundwater resources. U.S. Geological Survey Circular 1186.

Baalousha, H., 2008. Fundaments of groundwater modeling. In: Groundwater: Modelling, Management (Eds. L.F. Konig \& J.L. Weiss). Pp. 64 (113-130). https://doi.org/10.1146/ annurev.cellbio.20.010403.095114

Baharuddin, M.F.T., S.A.A. Tajudin, M.H.Z. Abidin and N.A. Yusoff. 2016. Simulation of sub-drains performance using Visual MODFLOW for slope water seepage problem. IOP Conf. Series: Materials Science and Engineering 136 (2016). doi:10.1088/1757$899 X / 136 / 1 / 012014$

Boisson, A., N. Guihéneuf, J. Perrin, O. Bour,B. Dewandel, A. Dausse, and J. C. Maréchal. 2015. Determining the vertical evolution of hydrodynamic parameters in weathered and fractured south Indian crystallinerock aquifers: insights from a study on an instrumented site. Hydrogeology Journa
123(4): 757-773. https://doi.org/10.1007/ s10040-014-1226-x

Carrol, R. W. H., G. M. Pohll, S. Earman, and R. L. Hershey. 2008. A comparison of groundwater fluxes computed with MODFLOW and a mixing model using deuterium: Application to the eastern Nevada Test Site and vicinity. Journal of Hydrology 361(3-4): 371-385. https://doi.org/10.1016/j.jhydrol.2008.08.005

CGWB. 2013. Ground Water Brochure, Nalgonda District. Central Groundwater Board, Ministry of Water Resources, Government of India. Vol. 492001

Fouépé Takounjou, A., V. V. S. Gurunadha Rao, J. N. Ngoupayou, L. Sigha Nkamdjou and G. E. Ekodeck. 2009. Ground water flow modeling in the upper Anga'a river watershed, Yaounde, Cameroon. African Journal of Environmental Science and Technology 3(10): 341-352. http://www.academicjournals.org/AJEST

Gleeson, T., Y. Wada, M.F.P. Bierkens and L.P.H. Beek. 2012. Water balance of global aquifers revealed by groundwater footprintA Research Letter. Nature 448: 200. https:// doi:10.1038/nature11295

Guihéneuf, N., A. Boisson, O. Bour, B. Dewandel, J. Perrin, A. Dausse, and J. C. Maréchal. 2014. Groundwater flows in weathered crystalline rocks: Impact of piezometric variations and depth-dependent fracture connectivity. Journal of Hydrology 511: 320-324. https:// doi.org/10.1016/j.jhydrol.2014.01.061

Guihéneuf, N., O. Bour, A. Boisson, T.L. Borgne, M. W. Becker, B. Nigon and J. C. Maréchal. 2017. Insights about transport mechanisms and fracture flow channeling from multiscale observations of tracer dispersion in shallow fractured crystalline rock. Journal of Contaminant Hydrology 206: 18-33. https:// doi.org/10.1016/j.jconhyd. 2017.09.003

Hariharan, V., and M. Uma Shankar. 2017. A review of Visual MODFLOW applications in groundwater modeling. IOP Conf. Series: Materials Science and Engineering 263. https:// doi:10.1088/1757$899 X / 263 / 3 / 032025$

Jovanovic, N. Z., S. Israel, G. Tredoux, L. Soltau, 
D.L. Maitre, F. Rusing,A. Rozanov, and N.V. Merwe. 2009. Nitrogen dynamics in land cleared of alien vegetation (Acacia saligna) and impacts on groundwater at Riverlands Nature Reserve (Western Cape, SouthAfrica). Water S.A. 35 (1): 37-44.

Khadri, S. F. R., and C. Pande. 2016. Groundwater flow modeling for calibrating steady-state using MODFLOW software: a case study of Mahesh River basin, India. Modeling Earth Systems and Environment 2(1):39 https://doi. org/10.1007/s 40808-015-0049-7

Kumar S., M. K. Choudhary, and R. Nayak. 2017. Groundwater Modelling in Bina River Basin, India using Visual MODFLOW. International Journal for Scientific Research \& Development 5 (5): 1398-1402.

Lasya, C. R. and M. Inayathulla. 2015. Groundwater flows analysis using Visual MODFLOW. IOSR Journal of Mechanical and Civil Engineering 12(2): 5-9.

Lerner D. N., A. Issar, and I. Simmers. 1990. A guide to understanding and estimating natural recharge. Int. Contribution to hydrogeology 8:345, I. A. H. Publ., Verlag Heinz Heisse.

McDonald, M.G., and A. W. Harbaugh. 1988. A modular three-dimensional finite-difference groundwater flow model. U.S. Geological Survey Techniques of Water-Resources Investigations, Book 6 (A1), Pp. 586.

Mondal, N. C., and V. S. Singh. 2009. Mass transport modeling of an industrial belt using visual MODFLOW and MODPATH: A case study. Journal of Geography and Regional Planning 2(1): 1-19.

Mondal, N.C. and V. P. Singh. 2012. Chloride migration in groundwater for a tannery belt in Southern India. Environmental Monitoring and Assessment 184(5): 2857-2879. https:// doi.org/ 10.1007/s10661-011-2156-x.

Mondal, N. C., 2019. Groundwater modeling using Visual MODFLOW in the last two decades in India: a review. International Journal of Science and Research 8(1): 27-38.
Saghravani, S.R., S. B. Mustapha, S. B., Ibrahim, M. K. Yusoff, M. El-Harbawi, and E. Randjbaran. 2012. Predicting groundwater flow and phosphorus fate in an unconfined aquifer using Visual MODFLOW. IJEES 3 (2): 167-176.

Sen, X., L. Yu, L. Shiliang, L. Wenping, W. Yanli, and P. Yabing. 2018. Numerical simulation for groundwater distribution after mining in the Zhuanlongwan mining area based on Visual MODFLOW. Environmental Earth Sciences 77:400. https://doi.org/10.1007/ s12665-018-7575-3

Shi, W., W. Zeng, and B. Chen. 2010. Application of Visual MODFLOW to assess the Sewage Plant accident pool leakage impact on groundwater in the Guanting Reservoir area of Beijing. Frontiers of Earth Science in China 4(3): 320-325. https://doi.org/10.1007/ s11707-010-0118-1

Singh, A., 2013. Groundwater modeling for the assessment of water management alternatives. Journal of Hydrology 481: 220-229.

Sklorz, S., M. Kaltofen, and B. Monninkhoff. 2017. Application of the FEFLOW groundwater model in the Zayandeh Rud catchment. In:Reviving the dying giant ( Eds. S. Mohajeri \& L. Horlemann), Springer, Cham.

Steiakakis, E., D.Vavadakis, M. Kritsotakis, K. Voudouris, and C. Anagnostopoulou. 2016. Drought impacts on the freshwater potential of a karst aquifer in Crete, Greece. Environ Earth Sci.75:507. https://doi.org/10.1007/ s12665-016-5509-5

Todd, D.K. and L.W. Mays. 2005. Groundwater Hydrology. Third Edition. John Wiley \& Sons, Inc.

Waterloo Hydrogeologic. 2015. Visual MODFLOW 2011.1: User's manual for professional applications in three-dimensional groundwater flow and contaminant transport modeling. Waterloo Hydrogeologic.

Web source, http:/www.google.com/earth/, retrieved on 20 January 2019. 